\title{
The Difficulties and Solutions of "the Belt and Road" in Promoting RMB Internationalization
}

\author{
Zicheng You ${ }^{a}$, Yujia Gu ${ }^{b}$ \\ School of business, Renmin University of China, Beijing, China. \\ arbsyouzicheng@163.com, brbsguyujia@163.com
}

\begin{abstract}
RMB internationalization is an important way for China to improve its international status and transform from a huge economic country to a powerful economic country. "The Belt and Road" is a new regional cooperation model, advocated by China. It promotes mutual development and prosperity of countries along "The Belt and Road". And it also plays an important role on pushing RMB internationalization. But, there are still many problems and difficulties in this process. The article will focus on the main difficulties and solutions of "The Belt and Road" in promoting RMB internationalization.
\end{abstract}

Keywords: "The Belt and Road"; RMB internationalization; Difficulties; Solutions.

\section{“一带一路”在推动人民币国际化进程中的困难及对策}

\author{
尤梓丞, 谷雨佳 \\ 中国人民大学商学院, 北京, 中国
}

摘 要: 人民币国际化是中国提高国际地位, 从经济大国过渡到经济强国的重要途径; “一带 一路” 是中国倡导的新型区域合作模式, 它不仅促进了沿线国家的共同发展和共同繁荣, 也 对加快人民币国际化进程起到了重要的推动作用。但是, 在此推进过程中仍面临诸多问题。 本文将对 “一带一路” 在推进人民币国际化进程中的主要困难展开分析, 并提出相应的对策 和建议。

关键词：“一带一路”；人民币国际化；困难；对策

\section{1. 前言}

“一带一路” 是 “丝绸之路经济带” 和 “21 世纪海上丝绸之路” 的简称。“一带” ，指的是 “丝绸之路经济带”，“一路”，指的是 “21 世纪海上丝绸之路”。根据规划, “一带一路” 将成为世界上跨度最长的经济大走廊, 涉及国家的总人口约 44 亿, 经济总量约 21 万亿美元, 分别约占全球的 $63 \%$ 和 $29 \%$ 。自中国于 2015 年首次提出 “一带一路” 倡议以来, 人民币国 际化进程得到了良好的发展机遇。通过 “一带一路” 所形成的贸易圈与投资圈, 一定范围内 以人民币为主要流通与结算货币的局面正在逐步形成。迄今为止，关于人民币国际化实现路 径的研究已有很多, 但在 “一带一路” 背景下的讨论相对较少。“一带一路” 作为中国实现 “走出去” 的主要战略之一, 其对人民币国际化的推动作用必然是关键的、长远的。所以分 析 “一带一路” 在推进人民币国际化时所面临的主要困难, 提出针对这些困难的合理对策, 是十分必要的。本文将阐述 “一带一路” 对人民币国际化的推动具体通过哪些方面实现, 目 前在此过程中遇到哪些主要障碍, 及对解决这些障碍的对策建议。 


\section{2. “一带一路” 对人民币国际化的推动作用}

\section{1 区域经济的形成}

“一带一路” 是对人民币周边化、区域化、全球化 “三步走” 规划的不断深化，是促进区 域经济合作的一项举措。“一带一路” 通过国家间的合作，增加了区域内国家的开放程度， 逐步形成以人民币为主要流通与结算货币的人民币投资与贸易圈，为人民币在区域经济中的 更广泛使用提供了机会。

\section{2 双边及多边贸易的增加}

“一带一路” 促进了中国与沿线国家之间的双边贸易及多边贸易的发展，贸易的发展直接增 加了使用人民币的需求。2017 年我国对 “一带一路” 沿线国家进出口 7.37 万亿元，同比增 长 $17.8 \%$, 高于我国整体外贸增速 3.6 个百分点, 占我国外贸总值的 $26.5 \%$, 其中出口 4.3 万 亿元，增长 $12.1 \%$ ，进口 3.07 万亿元，增长 $26.8 \%$ 。中国与沿线国家的多边贸易中更多地使 用人民币计价结算势必可以扩大人民币在沿线国家的影响力，推进人民币国际化进程。并且， 采用人民币作为结算货币可以规避汇率风险，降低交易成本，促进多边贸易的便捷有序发展。 2.3 对外投资的增加

“一带一路” 沿线国家基础设施严重缺乏。“一带一路” 沿线国家已经成为近年来中国企业 对外投资的新热点, 人民币债券和票据发行规模也在不断扩大。据 IMF 测算, 未来五年, 仅 “一带一路” 沿线国家基础设施建设累计投资额将超过三万亿美元。庞大的基础设施建设资 金的输出将使人民币的使用扩大到一带一路沿线国家，并使得人民币的使用常态化，加强人 民币的区域化进程，有利于人民币的进一步国际化。

\section{4 国际储备货币地位的提升}

人民币在 2016 年加入 SDR 货币篮子，标志着人民币国际化的重大突破，有利于扩大人民币的 使用范围。“一带一路”建设促使沿线各国同中国共同发展，导致了双方依存度增加，进而 增加对人民币的需求。“一带一路” 建设将提高人民币的使用，从而有利于人民币作为国际 储备货币地位的提升 [5]。

\section{3 “一带一路” 推行人民币国家化进程中面临的主要困难}

\section{1 沿线国家风险突出}

由于特殊的历史和地理位置, “一带一路” 沿线的许多国家政治局势不稳定、社会动荡, 政 治派别间存在尖锐矛盾斗争。在全球最高的十大地缘政治风险中, 前六大风险均集中在 “一 带一路” 沿线国家 (包括伊朗核危机、叙利亚危机、中国南海争端、印度半岛安全问题、俄 罗斯与乌克兰矛盾和北约东扩与俄罗斯利益冲突）。中国出口信用保险公司利用国家风险评 价模型从政治风险、经济风险、商业环境风险和法律风险 4 个角度分析和评估了 “一带一路” 沿线国家的风险级别。整体来看, “一带一路” 沿线国家评级为 5-9 级的国家占比为 84\%, 区域绝对风险水平处于相对高位。

表1 “一带一路” 沿线国家风险评级情况

\begin{tabular}{ccc}
\hline 等级 & 国家 & 风险水平 \\
\hline 1 & 新加坡 & 较低 \\
\hline 3 & 阿联酋等3国 & 中等偏低 \\
\hline 4 & 科威特等5国 & 等偏高 \\
\hline 5 & 俄罗斯等20国 & 较高 \\
\hline 6 & 印度等16国 & 较高 \\
\hline 7 & 伊朗等17国 & 偏高 \\
\hline 8 & 阿富汗 & 非常高 \\
\hline 9 & 叙利亚 & 最高 \\
\hline
\end{tabular}

极高的国家风险势必会影响 “一带一路” 建设中我国的贸易和投资活动，从而阻碍人民币国 际化进程。沿线中的小国家经济发展落后, 货币币值不稳定, 抵抗外来金融风险的能力弱, 
金融市场易发生剧烈波动。这使得我国政府和企业进行对外投资时难以预测这些国家的经济 走势 [4]。一些处于社会动荡中的国家没有长远的发展规划, 而 “一带一路” 建设中的多数投 资项目具有投资期限较长、收益回报率偏低的特点。这导致项目的投资收益难以准确预估, 容易因沿线国家政治、经济上的变动造成损失。一些政治局势不稳定的国家甚至会发生政权 更迭的情况, 如果新政府不认可之前签订的协议, 发生大规模违约现象, 将给中国政府和企 业带来巨大的冲击。

3.2 项目资金来源紧张

在 “一带一路” 建设中, 我国企业面临着严重的 “融资难” 问题, 项目的资金来源存在巨大 缺口。根据最新的亚开行的统计数据，仅亚洲地区的基础设施投资的资金缺口，每年就超过 一万亿美金。“一带一路” 建设项目中，一个获得金融服务的有效途径是通过中国进出口银 行, 而其业务集中在大企业和大项目上, 多数民营企业实际上难以获得其政策性支持。对于 民营企业和中小项目来说, 商业银行仍旧是获得金融服务的主要来源。以建行为例, 其目前 在 “一带一路” 沿线国家累计储备 268 个重大项目, 遍布 50 个国家和地区, 投资金额共计 4660 亿美元, 主要涉及电力、建筑、矿产、交通、油气、通信等基础设施建设项目。然而, 商业银行对 “一带一路” 项目提供的金融支持并不充分，大多数基础设施融资出现了错配的 情况。如上文提到的, “一带一路” 基础设施建设的特点是投资开发期较长, 收益率不稳定, 因此需要长期的、低利率的大额贷款作为支撑。然而, 目前 “一带一路” 基础设施融资基本 是以 “项目专项债” 的形式, 而 “项目专项债” 具有评级较低的特点。评级低, 商业银行就 难以提供长期的、低利率的大额贷款。企业面临 “融资难” ，制约了其对 “一带一路” 沿线 国家的投资，人民币国际化的进程也就收到了限制。除此之外，“一带一路” 沿线缺乏区域 性金融中心和成熟的金融合作组织。金融合作较为松散，也制约了人民币国际化吸纳资金的 能力。

3.3 货币网络效应的排斥

“一带一路” 在推动人民币国际化进程中的一大困难在于美元具有强大的使用惯性和网络效 应, 沿线国家对于国际经济往来中的货币选择具有很强的路径依赖, 短时间内难以改变。根 据货币的网络效应, 个人持有币种的决策依赖于对他人持有决策的预期, 如果大家都以同样 的方式作决策, 可能的结果是大家都没有动机去使用新的统一货币, 因为预期不明确, 个体 转换的成本太大, 从而导致大群体内的全局协调失败 [3]。从国际货币的发展进程来看, 英镑 用了 200 年的时间才战胜法郎与荷兰盾, 70 多年之后, 美元通过布雷顿森林体系的实施代替 了英镑, 成为世界霸主。从此以后, 美元的国际货币功能迅速发展, 在交易媒介、价值储藏 等方面发挥着难以替代的作用。虽然从理性的角度看, “一带一路” 的沿线国家使用人民币 代替美元来进行结算可以降低交易成本和汇率风险, 但是多年来的使用惯性已经形成了货币 网络效应。这种网络效应不断增加人们在经济活动中使用美元进行计价结算的频率，从而反 过来进一步强化美元的使用惯性, 形成了良性循环。这种良性循环具有强烈的排斥人民币国 际化的能力。

\section{4 相应的对策}

4.1 针对国家风险问题的对策

加强与 “一带一路” 沿线各国政府间的交流，建立起信息共享机制。充分的信息使我国政府 和企业能及时了解各国经济、政治等方面的动态, 做出更准确的投资及合作决策, 并在经济 波动来临之前拥有更充足的时间进行应对。第二, 设立政府层面的保障机制。通过与沿线国 家签订各类双边、多边协议, 来约束和规范政府信用和商业行为, 防范政府更迭带来的违约 风险 [1]。第三, 在区域内建立起监管协调机构。中国应协调各国, 共同对区域内金融风险进 行有效分析预警, 及时发现风险隐患并采取监管措施，共同维护区域性经济稳定发展。第四， 充分发挥保险的作用来降低企业面临的风险。设立 “一带一路” 专项政策性政策保险或鼓励 商业保险的介入，给企业 “走出去” 提供基本的保障和支持 [5]。 


\section{2 针对资金来源问题的对策}

第一，加强政策性金融支持。政府应从融资的角度，加大对 “一带一路” 建设项目的扶持力 度，扩大政策性贷款的金额及服务范围，争取让民营企业的中小型项目也能获得政府专项贷 款。政府可以整合相关国家的金融资源，通过与沿线国家的金融合作，来保障对企业的政策 性金融支持。第二，改善间接融资服务。商业银行应根据 “一带一路”建设项目资金需求的 特点, 在控制风险的前提下, 提供期限长, 利率低的专项贷款, 避免期限错配的情况。第三, 发展直接融资对 “一带一路” 建设的支持。中国要加强多层次资本市场的建设，依托政府信 用, 发行 “一带一路” 专项债券, 甚至与 “一带一路” 沿线国家的资本市场对接合作，向境 外金融市场发行专项债券 [2]。

\section{3 针对货币网络效应的对策}

第一，政府实施有效的干预。当政府以法律形式对统一货币流通保驾护航时，人们对他人持 有货币的预期会变的相当明确，因此网络效应会被瞬间打破，单一货币的流通便得到实现， 欧元区的快速形成就是依靠政府法律规定。虽然中国政府不能强制 “一带一路”沿线国家使 用人民币，但是通过对内明确的政策导向和对外具体的协商合作，政府可以改善个体对统一 货币的持有预期，有效削弱美元的网络效应，加速人民币国际化进程。第二，充分发挥技术 优势。技术进步可以有效减少人们改变货币使用习惯的时间，中国应充分发挥自己在移动支 付、第三方支付、电子商务、数字货币等领域的先进技术优势，创建全新的人民币支付清算 系统，通过有效的技术路径实现弯道超车，加快打破美元货币网络的进程。

\section{5 结论}

“一带一路” 的建设给人民币国际化带来了广阔的发展前景，通过形成区域经济、增加双边 和多边贸易、增加投资、提升国际储备货币地位，“一带一路” 成为将人民币推向世界的绝 佳机会。然而, 目前 “一带一路” 对人民币国际化的推进正面临着沿线国家风险突出、项目 资金来源紧张、货币网络效应排斥的挑战。针对沿线国家风险突出的问题，各国政府间应建 立起信息共享机制、信用保障机制，设立监管协调机构，开发 “一带一路”专项保险；针对 项目资金来源紧缺的问题，政府应扩大政策性金融支持的力度和范围，改善间接融资服务的 期限错配等情况, 通过专项债券等形式发挥直接融资的作用; 针对货币网络效应的排斥问题, 政府可以尝试通过政策导向干预人民对持有人民币的心理预期，并充分发挥中国在移动支付 等方面的技术优势。

\section{References}

[1]. Feng Li. FDI Risks in the Countries along the Belt and Road and the Countermeasures [J]. China Business and Market. Vol. 30 (2016) No. 2, p.115-121.

[2]. Zhihong Ren. Opportunities, Difficulties and Ways of the Belt and Road and RMB Internationalization [J]. Journal of South China Normal University (Social Science Edition). Vol. (2016) No. 3, p.28-34.

[3]. Yuefen Lin. Empirical analysis of the influence factors of RMB internationalization in the Belt and Road process [J]. Studies of International Finance. Vol. (2016) No. 2, p.75-83.

[4]. Jianyun Bao. The Investment and Financing Opportunity, Market Conditions and Risk Distribution in RMB Internationalization Created by the Belt and Road [J]. Tianfu New Idea. Vol. (2015) No. 1, p.112-116.

[5]. Zhang Fan Yu Miaojie Yu Jiantuo. The "Belt and Road" Initiative and the Future of the RMB Internationalization [J]. People's Tribune • Frontiers. Vol. (2017) No. 9, p.28-45. 